\title{
NOTES
}

\section{GTRI-02, a New Lipid Peroxidation Inhibitor from Micromonospora sp. SA246}

\author{
WoOn-Hyung YeO, Bong-SiK Yun ${ }^{\dagger}$, \\ Sang-SeOck Kim*, Eun-Kyung Park, \\ YOUNG-Ho KIM, ICK-DONG YoO ${ }^{\dagger}$ \\ and SEUNG-HuN $\mathrm{Yu}^{\dagger+}$
}

\author{
Korea Ginseng \& Tobacco Research Institute, \\ Taejon 305-345, Korea \\ ${ }^{\dagger}$ Korea Research Institute of Bioscience \\ and Biotechnology, KIST, Yusong, \\ Taejon 305-600, Korea \\ ${ }^{\dagger \dagger}$ Department of Agricultural Biology, \\ Chungnam National University, \\ Taejon 305-764, Korea
}

(Received for publication April 15, 1998)

Peroxidative disintegration of cells and organellar membranes by free radicals has been known to be involved in various pathological processes represented by the pathogenesis of diseases such as myocardial and cerebral ischemia, atherosclerosis, diabetes, rheumatoid arthritis, cancer-initiation, and aging processes. ${ }^{1 \sim 3)}$ Free radical scavengers are considered as protective agents against various diseases mentioned above. In our screening for free radical scavenging substances, a novel compound, GTRI-02 (1, Fig. 1), was isolated from a soil actinomycetes SA246, which was identified as Micromonospora sp. In this paper, we describe the isolation, structure determination, and free radical scavenging activity of compound $\mathbf{1}$.

The producing organism was inoculated into $100 \mathrm{ml}$ of seed culture medium, potato dextrose broth (Difco), in a $500 \mathrm{ml}$ Erlenmeyer flask. After 24 hours of incubation at $27^{\circ} \mathrm{C}$ on a rotary shaker $(250 \mathrm{rpm}), 1 \mathrm{ml}$ of this seed culture was transferred to $100 \mathrm{ml}$ of the same medium in a $500 \mathrm{ml}$ flask and incubated at $27^{\circ} \mathrm{C}$ for 96 hours on a rotary shaker $(250 \mathrm{rpm})$.

The culture filtrate $(5 \mathrm{~L})$ was extracted with EtOAc. The extract was concentrated under reduced pressure. The concentrated material was dissolved in a small amount of EtOAc and chromatographed on a silica gel column using a linear gradient elution of EtOAc- MeOH $(100: 10 \sim 100: 50)$. The active fractions were collected and concentrated in vacuo to dryness to yield a brownish powder. This powder was rechromatographed on a silica gel column with $\mathrm{CHCl}_{3}-\mathrm{MeOH}$ gradient elution (100:1 100:10). The active fractions were concentrated in vacuo and subjected to silica gel TLC developed with $\mathrm{CHCl}_{3}-\mathrm{MeOH}(100: 7)$. The active band with $\mathrm{Rf}$ value of 0.32 was scraped off and extracted with $\mathrm{CHCl}_{3}$ $\mathrm{MeOH}(70: 10)$ mixture. The extract was further purified by reverse phase TLC with $65 \% \mathrm{MeOH}(\mathrm{Rf} 0.58$ ) as a developing solvent to give $3 \mathrm{mg}$ of $\mathbf{1}$.

Physico-chemical properties of $\mathbf{1}$ are summarized in Table 1. Compound $\mathbf{1}$, obtained as a white powder was readily soluble in DMSO, $\mathrm{MeOH}$ and $\mathrm{CH}_{3} \mathrm{CN}$, and slightly soluble in EtOAc and $\mathrm{CHCl}_{3}$. Its $\mathrm{UV}$ spectrum showed maxima at 274, 232 and $211 \mathrm{~nm}$ in $\mathrm{CH}_{3} \mathrm{CN}$. Its IR spectrum suggested the presence of hydroxyl $\left(3470 \mathrm{~cm}^{-1}\right), \alpha, \beta$-unsaturated carbonyl $\left(1693 \mathrm{~cm}^{-1}\right)$ and aromatic ring moiety $\left(\mathrm{C}=\mathrm{C}, 1597\right.$ and $\left.1573 \mathrm{~cm}^{-1}\right)$. Molecular formula was determined to be $\mathrm{C}_{13} \mathrm{H}_{14} \mathrm{O}_{4}$ on the basis of FAB-MS spectrum in combination with ${ }^{1} \mathrm{H}$ and ${ }^{13} \mathrm{C}$ NMR spectral data (Table 2). ${ }^{1} \mathrm{H}$ NMR spectrum in DMSO- $d_{6}$ showed peaks attributed to aromatic methine at $6.60 \mathrm{ppm}$, oxygenated methine at $4.15 \mathrm{ppm}$, two methylenes at $3.03,2.77,2.71$ and 2.45 ppm, and two methyls at 2.36 and 2.29 ppm. ${ }^{13} \mathrm{C}$ NMR and DEPT spectra revealed signals due to two carbonyls at 205.7 and $197.3 \mathrm{ppm}$, one oxygenated $s p^{2}$ quaternary carbon at $157.1 \mathrm{ppm}$, four $s p^{2}$ quaternary carbons at

Table 1. Physico-chemical properties of GTRI-02.

\begin{tabular}{ll}
\hline Appearance & White powder \\
Molecular formula & $\mathrm{C}_{13} \mathrm{H}_{14} \mathrm{O}_{4}$ \\
FAB-MS $(m / z)$ & $235(\mathrm{M}+\mathrm{H})^{+}$ \\
{$[\alpha]_{\mathrm{D}}^{20}$} & $-10^{\circ}\left(c 0.2, \mathrm{CH}_{3} \mathrm{OH}\right)$ \\
$\mathrm{UV} \lambda_{\max }^{\mathrm{CH}_{3} \mathrm{CN}} \mathrm{nm}(\varepsilon)$ & $274(15,521), 232(14,921)$, \\
& $211(16,898)$ \\
$\mathrm{IR} v_{\max }^{\mathrm{KBr}} \mathrm{cm}^{-1}$ & $3470,3140,1693,1655,1597$, \\
& $1573,1300,1279,1230,1064$ \\
Rf value on TLC & $0.32^{\mathrm{a}}$ \\
& $0.58^{\mathrm{b}}$ \\
Solubility & $\mathrm{DMSO}, \mathrm{MeOH}, \mathrm{CH}_{3} \mathrm{CN}$ \\
\hline a Silica gel: $\mathrm{CHCl} \mathrm{HCl}_{3}-\mathrm{MeOH}(100: 7)$. \\
b ODS: $\mathrm{MeOH}-\mathrm{H}_{2} \mathrm{O}(65: 35)$.
\end{tabular}


Table 2. ${ }^{1} \mathrm{H}$ and ${ }^{13} \mathrm{C}$ NMR spectral data for GTRI-02 in DMSO- $d_{6}$.

\begin{tabular}{lcl}
\hline Positions & $\begin{array}{c}{ }^{13} \mathrm{C} \text { chemical } \\
\text { shifts, ppm }\end{array}$ & \multicolumn{1}{c}{$\begin{array}{c}{ }^{1} \mathrm{H} \text { chemical } \\
\text { shifts, ppm }\end{array}$} \\
\hline 1 & 197.3 & \\
2 & 49.2 & $2.71(\mathrm{dd}, 16.0,3.6)^{\mathrm{a}}$ \\
& & $2.45(\mathrm{dd}, 16.0,6.8)$ \\
3 & 64.9 & $4.15(\mathrm{~m})$ \\
4 & 39.9 & $3.03(\mathrm{dd}, 16.0,3.6)$ \\
& & $2.77(\mathrm{dd}, 16.0,6.8)$ \\
$4 \mathrm{a}$ & 145.5 & \\
5 & 113.8 & $6.60(\mathrm{~s})$ \\
6 & 157.1 & \\
7 & 130.9 & \\
$7-\mathrm{CO}_{7-\mathrm{CH}_{3}}$ & 205.7 & \\
8 & 32.4 & $2.36(\mathrm{~s})$ \\
$8-\mathrm{CH}_{3}$ & 137.7 & \\
$8 \mathrm{a}$ & 18.5 & $2.29(\mathrm{~s})$ \\
\hline
\end{tabular}

a Proton resonance multiplicity and coupling constant $(J=\mathrm{Hz})$ in parentheses.

$145.5,137.7,130.9$ and $123.4 \mathrm{ppm}$, one $s p^{2}$ methine at $113.8 \mathrm{ppm}$, one oxygenated methine at $64.9 \mathrm{ppm}$, two methylenes at 49.2 and $39.9 \mathrm{ppm}$ and two methyls at 32.4 and $18.5 \mathrm{ppm}$. COSY spectrum gave a partial structure, $-\mathrm{CH}_{2}-\mathrm{CH}(-\mathrm{O})-\mathrm{CH}_{2}-$. The structure of 1 was unambiguously assigned by the HMBC experiment (Fig. 1). It showed long-range correlations from 2-H (2.71, 2.45 $\mathrm{ppm})$ and $3-\mathrm{H}(4.15 \mathrm{ppm})$ to the carbonyl carbon at $197.3 \mathrm{ppm}$, and from $4-\mathrm{H}$ at 3.03 , and $2.77 \mathrm{ppm}$ to three $s p^{2}$ carbons at $145.5,123.4$ and $113.8 \mathrm{ppm}$. Also long-range correlations from the methine proton at $6.60 \mathrm{ppm}$ to carbons at $157.1,130.9,123.4$ and $39.9 \mathrm{ppm}$ and from the methyl proton at $2.29 \mathrm{ppm}$ to three $s p^{2}$ quaternary carbons at 137.7, 130.9 and $123.4 \mathrm{ppm}$ revealed that this compound had the skeleton of tetralone ${ }^{4,5)}$. The methyl proton at $2.36 \mathrm{ppm}$ showed long-range correlation with two quaternary carbons at
Fig. 1. Long-range couplings observed in the HMBC experiments on GTRI-02.

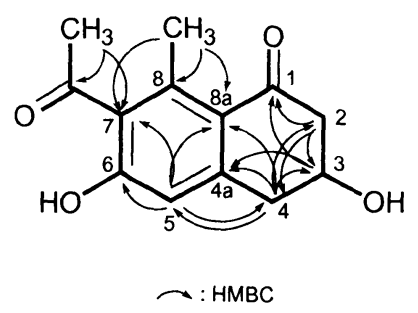

205.7 and $130.9 \mathrm{ppm}$ indicating that an acetyl group must be attached to C-7. Thus the structure of 1 was determined to be 7-acetyl-3,6-dihydroxy-8-methyl tetralone.

Lipid peroxidation inhibitory activity was measured according to the methods of OHKAWA et al ${ }^{6)}$ Compound 1 inhibited lipid peroxidation with a $\mathrm{IC}_{50}$ value of $1.89 \mu \mathrm{g} / \mathrm{ml}$ which is about half the activity of vitamin $\mathrm{E}$ $\left(\mathrm{IC}_{50} ; 0.91 \mu \mathrm{g} / \mathrm{ml}\right)$.

\section{References}

1) Fridovich, I.: Biological effects of the superoxide radical. Arch. Biochem. Biophys. 247: 1 11, 1986

2) Halliwell, B. \& J. M. C. Gutteridge (Ed.): Lipid peroxidation: a radical chain reaction, In Free radicals in biology and medicine. 2nd ed., pp. 188 267, Clarendon Press, Oxford, 1989

3) Kato, S.; K. Shindo, Y. Yamagishi, M. Matsuoka, H. KawaI \& J. Mochizuki: Phenazoviridin, a novel free radical scavenger from Streptomyces sp.: Taxonomy, fermentation, isolation, structure elucidation and biological properties. J. Antibiotics 46: 1485 1493, 1993

4) Findlay, J. A. \& D. Kwan: Scytalone (3,6,8-trihydroxytetralone), a metabolite from a Scytalidium species. Can. J. Chem. 51: 1617 1619, 1973

5) Findlay, J. A. \& D. Kwan: Metabolites from a Scytalidium species. Can. J. Chem. 51: 3299 3301, 1973

6) Ohkawa, H.; N. Ohishi \& K. Yagi: Assay for lipid peroxides in animal tissues by thiobarbituric acid reaction. Anal. Biochem. 95: 351 358, 1979 